\title{
Evaluating diatom succession: some pecularities of the Great Lakes case
}

\author{
Eugene F. Stoermer \\ Center for Great Lakes \& Aquatic Sciences, University of Michigan, Ann Arbor, MI 48109-2099, USA
}

Received 9 June 1992; accepted 16 December 1992

Key words: Diatoms, Laurentian Great Lakes, paleolimnology

\begin{abstract}
Succession of diatom communities in the Laurentian Great Lakes has several unusual aspects related to physical and chemical characteristics peculiar to these large systems and the constraints these conditions impose upon species which inhabit the Great Lakes. In such systems, paleolimnological reconstructions based on strict analogy to succession patterns in smaller lakes may be incomplete and, in some cases, positively misleading. In the Great Lakes, diatom accumulation rates appear to be regulated by interaction between concentration and supply rates of phosphorus and dissolved silicate. As phosphorus loadings increased historically, storage of diatom frustules in sediments was first increased, then limited, as concentrations of dissolved silica were reduced to levels limiting to diatom growth. Qualitative aspects of the diatom flora are also affected. Indigenous species adapted to growth in winter persist, while those with abundance maxima in summer are extirpated, presumably due to silica limitation in the summer epilimnion. Severe silica limitation also results in shifts to dominance by species whose growth strategies are particularly well adapted to sequestering dissolved silica. Because it is necessary to know the historical context in order to correctly interpret current changes in the Great Lakes diatom flora, paleolimnological studies have proven particularly valuable.
\end{abstract}

\section{Introduction}

In all branches of science, consideration of extreme or novel cases often proves generally instructive as to the functioning of complex systems. For several years I have studied the Laurentian Great Lakes, a system which, by its very magnitude, qualifies as unusual. Partially because of factors associated with scale, processes within the Great Lakes are also unusual in the sense that, although the same basic physical laws apply in all systems, the timing and magnitude of biological responses cannot necessarily be implied by analogy to typical small lakes.

This presents a particularly difficult problem in paleolimnological studies. Because very large lakes are a scarce feature of the earth's physiography (Herdendorf, 1982), there is no possibility of developing calibration sets containing a significant number of lakes of the same size, latitude, and geological history. Unfortunately, useful long-term data bases of limnological observations from the Great Lakes are also lacking. We are thus faced with constructing historic inferences from a combination of less than perfect external analogy and limited internal observation. There are two points that somewhat mitigate these difficulties. The first is that, because of the pattern of European settlement in North America and resource distribution, some parts of the system 
are more grossly perturbed than others. Thus some degree of useful inference regarding anthropogenic effects can be gained by modern comparison of different geographic regions within the Laurentian Great Lakes system. The second is that, although the time series of useful observation is limited, the system was very intensively observed from ca 1970 to ca 1980, due to practical concerns with water quality. Thus biological, particularly phytoplankton, data of higher density and quality are available for some regions of the Great Lakes than for nearly any other aquatic system. Although this data base is substantial, it is surprisingly difficult to access because much of it is reported in the so-called 'gray literature' (reports and special papers which have limited distribution). As a point of departure, it may be appropriate to list some of the ways in which the Laurentian Great Lakes differ from other systems.

Compared to most other very large lakes of the world, the Laurentian Great Lakes were formed relatively recently. So far as is presently known, they date only from the latest Pleistocene and did not reach their present configuration until ca 4000 year ago (Karrow \& Calkin, 1985). Thus their flora and fauna may have not had sufficient time to evolve specific adaptations to conditions in the lakes and are, to some extent, maladapted. Further, the Laurentian Great Lakes are effectively isolated from other, more ancient large lakes, hence the probabilities of transport of populations well adapted to conditions in large, temperate lakes from these sources is small. Conversely, the Laurentian Great Lakes are not effectively isolated from smaller lakes and from marine and estuarine sources of potentially invading biotic populations. Because transoceanic shipping enters the Laurentian Great Lakes, there exists an efficient vector for introduction of Eurasian species. As might be expected from these considerations, the biota of the Laurentian Great Lakes has been significantly modified since European settlement (Mills et al., 1991).

The Laurentian Great Lakes span major climatic and vegetation zones. In their original state, the lakes formed an extension of range for many boreal organisms into the temperate zone. Because of thermal stratification, there exist habitats where annual water temperature variation is only on the order of 1 to $4{ }^{\circ} \mathrm{C}$ even though regional air temperature variation extremes are more on the order of +40 to $-40^{\circ} \mathrm{C}$. In the case of algal populations, water transparency of the preEuropean Laurentian Great Lakes system provided the other necessary condition for a habitat with ecological conditions which varied only slightly during the annual seasonal cycle (Kingston et al., 1983).

Because of their great physical mass, heating and cooling cycles in the Laurentian Great Lakes significantly lag those of the surrounding land mass and smaller lakes embedded in that land mass. Thus, organisms in the lakes are subject to different temperature/insolation relationships than those in small lakes. The great thermal capacity of the Laurentian Great Lakes also causes physical fronts, such as the spring thermal bar (Huang, 1972), to be much more conspicuous and probably more ecologically important in these bodies of water than in most smaller lakes.

The surface area of the Laurentian Great Lakes is large relative to their total drainage. On the order of $30^{\circ}$ of all water entering the system comes from precipitation falling directly on the lake's surfaces. Because of this, and the fact that much of the northern part the Laurentian Great Lakes drainage basin is in ancient rock formations very resistant to dissolution, major algal nutrient concentrations bear the signature of continental rainfall (Weiler, 1978). Waters in least perturbed parts of the system are very deficient in phosphorus, moderately deficient in silica, but relatively rich in nitrogen. For the same reasons, the Great Lakes are particularly sensitive to loadings from the atmosphere, which has become a significant problem in the modern era.

The volume of the Laurentian Great Lakes is large relative to their annual water income. Renewal times range from $c a 200$ yrs in Lake Superior to ca 2 yrs in Lake Erie (Quinn, 1992). This means that immediate regulation of algal growth processes by nutrients in the Laurentian Great Lakes is more dependent upon internal processes 
(remineralization and recycling) than upon annual external loadings, especially in the headwater lakes. A similar condition exists in the lower lakes, despite their apparently much shorter renewal times, because a major fraction of their total water income comes from the adjacent upstream lake in the system. The difference being that biotic processing of influent materials has already taken place in the upstream lake. It needs to be recognized that there are a couple of confounding time-related considerations that complicate the above statement, in the context of diatom records preserved in Great Lakes sediments. The first is that, although the internal recycling versus external loading argument is true over short time intervals, external loadings drive change in the systems over long time intervals because of differences in relative efficiency of recycling major plant nutrients (Schelske et al., 1986). The second point is that, because of recycling, nutrient depletion is never complete, even in the context of an annual cycle. Because the Laurentian Great Lakcs are quite deep, but are vigorously mixed during winters, there always exists some considerable store of any nutrient, some fraction of which will be returned to the euphotic zone during winter circulation.

In terms of nutrient effects on diatoms, these considerations indicate that phosphorus is the prime nutrient controlling primary production in Laurentian Great Lakes. In these systems, silicon becomes limiting before nitrogen (Schelske \& Stoermer, 1971, 1972), and there are several stages of limitation, depending upon the extent of external phosphorus loading (Schelske et al., 1983).

It should be stressed that the Laurentian Great Lakes are grossly perturbed systems, although commonly employed small lake nomenclature does not adequately convey state changes which have taken place (Beeton, 1966). As an example, Lake Huron can be labelled oligotrophic, on the basis of average system phytoplankton standing crop or primary production, even though some segments are ultra-oligotrophic and others are very eutrophic (Vollenweider et al., 1974) according to the same measures. $A t$ the same time biotic communities, at all levels, from predatory fish to phytoplankton, and in all segments of the ecosystem, are vastly and probably permanently modified. Part of this apparent confusion results from the simple fact that parameters such as standing crop and production are very conservative, in the sense that they are not very sensitive to perturbation (Schindler, 1985). However, the lakes are also subject to numerous other effects. The Laurentian Great Lakes have been subjected to greatly enhanced loadings of some trace metals known to be toxic to algal populations and a melange of synthetic organic compounds which may modify growth or reproductive capacity (Sicko-Goad \& Stoermer, 1988).

Because of these considerations, it has been necessary to reinspect some commonly accepted truisms concerning diatom species succession and interpretation of absolute and relative abundance profiles in our work on the Laurentian Great Lakes. I will attempt to summarize the most important of these conclusions because they are important to understanding how ecological changes are recorded in sedimentary diatom assemblages in the Great Lakes, and probably more generally in large. deep, temperate lakes.

\section{Characteristics of diatom stratigraphies from the Laurentian Great Lakes}

\section{Quantitative relationships}

Quantitative trends in Great Lakes diatom communities proved difficult to interpret for pioneering investigators. Peterson's (1975) quantitative data from a core in eastern Lake Erie show little trend, although Peterson concluded that the small changes in relative species composition present indicated that "even in the eastern basin of Lake Erie the phytoplankton assemblage is beginning to respond to change'. This conservative conclusion is strikingly different than those subsequently reached by Frederick (1981), Harris \& Vollenweider (1982), and Stoermer et al. (1987), all of whom concluded that substantial change in Lake Erie's phytoplankton assemblages had begun with 
large-scale western settlement and forest clearance. In retrospect, it appears that the 'unusually large' ( $5797 \mathrm{yr}$ ) age obtained by extrapolating Peterson's ${ }^{14} \mathrm{C}$ dates to the surface reflect loss of some substantial portion of near-surface sediments from Peterson's core. Parker \& Edgington (1976) concluded that the large decline in diatom abundance with depth in cores from southern Lake Michigan must be caused by post burial dissolution, and that 'the permanent sediment is probably not a major sink for particulate biogenic silica in Lake Michigan'. They thus concluded that quantitative estimates of diatom abundance did not provide a useful index of lake trophic state, even though their (Parker \& Edgington, 1976) relative abundance data "suggest a floristic change consistent with progressive enrichment of the lake'. Parker \& Edgington apparently rejected the hypothesis that both concentration and relative abundance data reflected eutrophication on the basis of their calculations of system production. Frederick (1981) was even more explicit. He found 'productivity peaks' in the late 1800 's which he considered "incongruous" ... "in light of the known history of Lake Erie'. He further maintained that 'No event in the late 1800 's in the I ake Erie basin could account for the tremendous increase in productivity as indicated by the quantitative profiles'.

Schelske et al. (1983) presented a model, based partially on earlier experimental work on Lake Michigan (Schelske \& Stoermer, 1971, 1972), which rationalized Parker \& Edgington's (1976) and Frederick's (1981) quantitative observations. Subsequent quantitative studies of diatoms in Great Lakes cores (Stoermer et al., 1985a, b, c, 1987, 1990a, 1991; Wolin et al., 1988, 1991), in my opinion, conform to this model. According to Schelske et al. (1983), 'peaks' of the type observed by Frederick (1981) result from increased diatom accumulation caused by increased nutrient, particularly phosphorus, loading, followed by decreased accumulation resulting from silica limitation as demand, due to increased diatom growth, outstrips annual external supply and exhausts internal stores of dissolved silica. The rate at which this process occurs is dependent upon a number of factors including: the mean residence time of a given lake, external loading rates of phosphorus and silica to the lake, and relative recycle rates of phosphorus and silica within the system. Silica depletion also has a seasonal component, in that available silica levels are most severely reduced in the surface waters during summer stratification. Due to these interacting factors, several stages of algal response to silica limitation can be identified in Great Lakes sediment sequences (Schelske, 1991):

1. A quasi-steady state prior to European settlement.

2. A period of increased diatom accumulation due to increased nutrient loading.

3. Decreased accumulation due to silica limitation during summer stratification.

4. Further decrease in accumulation due to silica limitation during lake circulation.

5. Increased diatom accumulation due to reductions in phosphorus loading to the system.

Due to the physical factors enumerated above, their position in the system, and the intensity and duration of human influence, there are considerable differences in response stage of the different lakes within the Great Lakes system. Lake Ontario (Stoermer et al., 1985a; Schelske et al., 1988; Wolin et al., 1991) and eastern Lake Erie (Frederick, 1981; Stoermer et al., 1987) appear to have passed through all of the stages outlined above. Lake Michigan apparently was approaching stage 4 during the early 1970 's (Stoermer et al., 1990a) while Lake Huron is in early stage 3 or late stage 2 (Wolin et al., 1988) and Lake Superior is still in stage 2 (Stoermer et al, 1985c). It also should be realized that certain local regions within the Laurentian Great Lakes system do not show the same type of quantitative profiles found in offshore deposition basins. These are relatively shallow areas subject to high annual silica loadings, such as the Bay of Quinte of Lake Ontario (Stoermer et al., 1985b), Green Bay of Lake Michigan (Stoermer et al., 1991) and probably Saginaw Bay of Lake Huron and the Western basin of Lake Erie, although no cores from these 
areas have been studied. In these areas, nutrients, including silica, may be replenished at any time during the seasonal cycle by pulses of riverine loading due to storm events, complete circulation of the water column due to wind stress, or upwelling. Such events also, of course, occur in the nearshore regions of the main lakes, but the areas affected are so relatively small, compared to the euphotic volume of the offshore waters, that the event record is so diluted by microfossil contributions from the offshore waters that it cannot be (or at least has not been) resolved in cores from deep sedimentation basins.

There are a number of points that arise from consideration of the quantitative relationships discussed above that are certainly important to interpreting successional patterns in other large, originally oligotrophic lakes and, to a lesser but still significant extent, in many smaller lakes. The first is that productivity conditions which existed in the Laurentian Great Lakes prior to the influence of European settlers have few, if any, modern analogs. Paleolimnologic data indicates that system production was very low and, compared to modern situations, particularly low in plankton communities. In common with most other north temperate lakes, the available evidence suggests chrysophytes were more abundant, relative to diatoms, than in modern communities. Our data also indicate that benthic production was of greater relative importance in such 'pristine' associations. Our results also indicate that some populations in these benthic associations are the most sensitive to ecologic change. Examples are species such as Didymosphenia geminata (Lyngb.) M. Schmidt, once generally distributed in the upper lakes but now restricted to Lake Superior, and Melosira undulata (Ehrenb.) Kütz., once common in the Bay of Quinte (Stoermer et al., 1985b) and Green Bay (Stoermer et al., 1991), but extirpated soon after European settlement. It is clear that the earliest available quantitative conventional limnological data portrays greatly perturbed systems undergoing rapid change, rather than an equilibrium state. This is an important realization, because much ecologic theory and model construction assumes a known, or know- able, steady state condition. In the Laurentian Great Lakes departures from steady state are obvious, because changes in the biota and geochemical conditions occurred so rapidly. Although the degree of change in records from other types of systems may be as as large or larger, they are generally much less obvious because they started from higher trophic state and occurred incrementally, over long periods of time.

The Great Lakes paleolimnological record also emphasizes the significant and lasting effects of events associated with removal of the original forest and introduction of agriculture. Regional stream hydrographs have been substantially (Smith, 1972) and permanently modified, as have the chemical loadings carried by streams entering the Great Lakes. Although evidence to the contrary is available (Mackay, 1930), the generally held opinion in the past has been that serious fundamental changes in Great Lakes ecosystems are relatively recent, occurring mostly during the past 50 years. Well known destruction of important fish stocks (Baldwin \& Saalfield, 1962; Beeton, 1969), some of which occurred before 1900 (Parsons, 1973), were almost universally attributed to proximate causes, such as overfishing and habitat destruction. Paleolimnological studies suggest that declines in commercially important fish stocks were preceeded by large-scale changes in many factors of the lake's ecology and that factors usually cited may have been only the terminal insult to populations which were already under severe stress due to modification of lake conditions and the foodchain.

When attempting to compare and interpret records of diatom suecession, it is important to realize that the history of human influences, and the pattern of succession driven by such influences, is very different in North America than in Europe and many other parts of the world. On this continent, an industrial culture was imposed on a landscape little modified by its indigenous peoples in a matter of a few centuries. In the Great Lakes region the main part of this transition took place between 1800 and 1900. Within the basins of individual lakes it occurred in a few decades. Thus the tempo of ecological change 
was much more rapid and the mode more violent in North America, and particularly in the Great Lakes region, than in Europe. Since most of our autecological literature pertaining to diatoms is derived from Europe, or influenced by paradigms developed in Europe, it is often necessary to rethink some established constructs in the context of the North American experience.

Many recent studies point to the conclusion that the effects of certain human activities are transported far beyond their origin, imposing a new level of poorly anticipated ecological change. Our work on less perturbed regions of the Great Lakes (Stoermer et al., 1985c) and even less modified large lakes (Stoermer et al., 1990b) convinces me that large lakes are particularly susceptible to effects of materials transported via the atmosphere. One must also conclude that such effects are more general than commonly realized and that it will be increasingly important to consider widespread or global causalities of change in aquatic systems other than the Great Lakes.

\section{Qualitative relationships}

High relative abundance of certain Cyclotella species, the oligotrophic Cyclotella association of Hutchinson (1967), has almost universally been cited as indication of low nutrient loading and unmodified lake conditions. The taxonomy of this group and its associated nomenclature is currently in such a state of flux that assigning names to the species involved is difficult. However, names such as Cyclotella bodanica Grun., C. comensis Grun., C. michiganiana Skv., C. ocellata Pant., C. radiosa (Grun.) Grun. (C. comta pro parte), and C. stelligera Cleve et Grun. have often been applied to the morphotypes common in the Great Lakes. In the Great Lakes, and some other small inland lakes (Engstrom et al., 1985), it is evident that these taxa reach their highest relative abundance in post-settlement sections of the record, apparently after some degree of enhanced nutrient input. Further, it is evident that these species disappear from some parts of the Great Lakes system (i.e., Lake Ontario, Stoermer et ai., 1985a). but remain present and relatively abundant in others (i.e., Green Bay of Lake Michigan, Stoermer et al., 1991), even though the 'trophic level' of the systems is similar, according to levels of algal standing crop and production.

Besides their apparent ability to grow in waters with low measurable nutrient levels, these species have a number of other characteristics in common:

1. They are most abundant during summer stratification (Stoermer \& Ladewski, 1976, 1978).

2. They are particularly abundant in the deep chlorophyll layer (Fahnenstiel \& Glime, 1983).

3. They apparently exhibit little morphological plasticity associated with nutrient concentration.

4. They appear to have little vegetative survival capacity (Sicko-Goad et al., 1989).

Based on consideration of these factors, it appears that the occurrence and abundance of these, and probably other 'oligotrophic' taxa, is governed at least as much by adaptions to a particular physical niche (Moll \& Stoermer, 1982), as by nutrient availability per se, nutrient competition, or other biotic interactions. Based on our observations in the Great Lakes, it appears that low absolute and moderate relative abundance of these species, characteristic of the period prior to extensive European settlement in the region, results from phosphorus supply so low that phytoplankton growth in the entire euphotic zone was severely limited during summer stratification, even though nitrogen and silicon remained present in cxcess. Their proportional representation, compared to the more eurytopic species discussed below, was relatively low because the latter species have their maximum growth period during periods when the lakes are circulating, hence have access to nutrient supplies 'stored' in the hypolimnion on an annual basis. Initial increases in phosphorus loading, particularly increased loading during summer months, alleviates summer phosphorus limitation to some degree and particularly favors growth of the "oli- 
gotrophic' Cyclotella taxa and greatly increases their proportional representation in the sedimentary record. Decline and eventual complete collapse of these populations occurs when further increases in phosphorus loading results in secondary nutrient (silicon) limitation in the euphotic zone. This both effectively halts summer diatom growth and, by switching available nutrients to chlorophytes and cyanophytes, helps 'shade out' the sub-thermocline phytoplankton habitat.

As an aside, it should be pointed out that the above argument does not necessarily have anything to do with assumptions derived from nutrient competition theories developed by Tilman (1977), partially on the basis of Great Lakes data. The Cyclotella species used by Tilman in his experiments were members of the C. meneghiniana Kütz. complex which apparently has substantially different environmental requirements than the species discussed above. In the Great Lakes, distribution of C. meneghiniana, and similar morphotypes, is restricted to nearshore areas, particularly in the vicinity of large rivers. It appears that gradients in its abundance in such regions is due mainly to dilution (Sell et al., 1984).

Another apparent peculiarity of diatom relative abundance records from the Great Lakes is the abundance of species generally reported to be tolerant of mesotrophic to eutrophic conditions in samples deposited in the pre-settlement era. Such species are also abundant late in the sequence from areas which have been significantly modified.

Besides their apparent ability to grow in waters with relatively high measurable nutrient levels, these species have a number of other characteristics in common:

1. They are most abundant during winter circulation or at the beginning of spring stratification (Stoermer \& Ladewski, 1976, 1978).

2. They are generally distributed throughout the water column. Transient maxima may be established in the spring thermocline, but these disappear soon after establishment of full stratification (Schelske \& Stoermer, 1984).
3. They exhibit considerable morphological plasticity associated with nutrient concentration (Stoermer et al., 1985d; Stoermer et al., 1989; Theriot, 1987; Theriot \& Stoermer, 1984; Theriot et al., 1988).

4. They appear to be able to survive sinking to the sediments in a vegetative state for considerable periods of time (Sicko-Goad et at., 1989).

Included in this group are such species as Aulacoseira islandica (O. Müll.) Simonsen, $A$. subarctica (O. Mül1.) Haworth, Stephanodiscus alpinus Hust., S. medius Hak., and S. niagarae Ehrenb. Based on our observations, it appears that these species are optimized to grow under light limitation, and indced to survive substantial periods without illumination. In the Great Lakes this makes available nutrient pools available during winter circulation. It also appears that the competitive advantages of these adaptations is further enhanced through the ability to mitigate the effects of silica limitation by altering their morphology to minimize silica requirements. Given these capabilitics, it is not surprising that these species are relatively abundant both in pre-settlement sequences, when summer production is generally nutrient limited, and in severely eutrophied parts of the system, where summer diatom production is minimal due to silica limitation. The important point is that reliance on the relative abundance of these species as an indication of trophic status, without consideration of their biological capabilities in the context of the system they inhabit, can be misleading.

Other species share the characteristics of morphological plasticity and prolonged vegetative survival with the above group but have higher and narrower temperature optima (Stoermer \& Ladewski, 1976, 1978) and apparently even higher nutrient requirements. Included in this group are species considered classic cutrophication indicators such as Fragilaria capucina Desm., Stephanodiscus binderanus (Kütz.) Krieg., S. binderanus var. oestrupi (A. Cleve) A. Cleve, S. hantzschii Grun., S. hantzschii var. tenuis (Hust.) Hăkansson \& Stoermer, and S.parvus Stoermer \& 
Håkansson. All of these taxa are polymorphic to some degree (Stoermer et al., 1979; Håkansson \& Stoermer, 1984; Stoermer \& Håkansson, 1984; Hákansson, 1986). In the Great Lakes their maximum abundance is associated with the spring thermal bar (Huang, 1972). In most parts of the system they reach greatest population density in the nearshore zone (Stoermer, 1968; Lorifice \& Munawar, 1974), although they spread to the offshore regions of Lake Ontario (Stoermer et al, 1974) and Lake Erie (Hohn, 1969). Other species with apparently similar nutrient requirements, but higher temperature optima (Cyclotella meneghiniana, C. cryptica Reiman, Lewin \& Guillard, $C y$ clostephanos tholiformis Stoermer, Håkansson \& Theriot, C. invisitatus (Hohn \& Hellerman) Theriot, Stoermer \& Håkansson) remain restricted to nearshore zones in the modern flora. All, however, may be recovered from samples taken from offshore sedimentation basins, even of lakes which have only local areas of significant eutrophication (Wolin et al, 1988). This appears to support the conclusion of Thayer et al. (1983) that the deep sedimentation basins of the Great Lakes capture an integrated history of events in the entire basin. One of the usual aspects of diatom succession in highly perturbed areas of the Great Lakes is that recent increases in species, such as those cited above, which have been considered indicators of eutrophication in the classic literature, may actually signal relaxation of nutrient stress. Wolin et al. (1991) have postulated that recent increases in the abundance of these species results from lower phosphorus loading, which results in less winter production and which, in turn, results in silica being available later in the annual cycle, the optimal growth period for these species. In Lake Ontario (Stoermer et al., 1985a) these species previously increased, then declined as diatom growth became increasingly limited by availability of dissolved silicate.

One interesting, but as yet unproven speculation is that some of the above species, notably Stephanodiscus binderanus, were not part of the original flora of the Great Lakes and perhaps were not indigenous to North America. The sudden appearance of $S$. binderanus in massive abun- dance (Brunel, 1956; Stoermer et al., 1985a) argue that it may have been introduced to the Great Lakes through ballast water discharge by transoceanic ships or some similar vector. Diatom biogeography, and particularly the spread of exotic species, is a topic certainly worthy of further attention in paleolimnologic studies.

Another unusual component of sedimentary diatom assemblages in the deep basins of the Great Lakes are a number of species whose active growth is confined to regions of the lakes shallow enough so they mix completely during the summer. These taxa appear to share the characteristics of:

1. Apparent high nutrient demand for growth.

2. Prolonged vegetative survival in sediments.

3. Maximum abundance at relatively high $\left(>17^{\circ} \mathrm{C}\right.$ ) water temperatures.

4. Rapid sinking velocities.

The most conspicuous members of this group are locally abundant planktonic species such as $A C$ tinocyclus normanii var. subsalsa (Juhl.-Dannf.) Hust. and Aulacoseira granulata (Ehrenb.) Simonsen, but a number of taxa not usually present in the plankton in more than trace abundance except in the Great Lakes, such as Amphipleura pellucida (Kütz.) Kütz. (Holland \& Claflin, 1975; Stoermer \& Stevenson, 1980; Stoermer et al., 1991) have similar occurrence patterns. The same is true of a number of primarily benthic, epipelic taxa which are routinely entrained into the plankton (Cymatopleura spp, Entomoneis ornata, some species of Nitzschia, Surivella spp.). By periodically sinking and being re-entrained into the plankton, these species are apparently able to escape secondary nutrient limitation and thrive in relatively shallow areas of the Great Lakes which are nutrient enriched. Some fraction of the remains of the populations produced are deposited in deep sedimentation basins of the lakes, even though the species do not occur in the plankton of these deep water sites in more than trace quantities.

Many readers will note that some of the species common in eutrophied areas of the Great Lakes tolerate quite high salinities (e.g. Actinocyclus nor- 
manii var. subsalsa, Cyclotella cryptica), typical of estuaries, while others are often abundant in inland waters with elevated dissolved solids levels. While it is true that levels of dissolved solids in the Great Lakes have increased, apparently due to anthropogenic effects (Beeton, 1969), current conductivity values $\left(100-400 \mu \mathrm{S} \mathrm{cm} \mathrm{cm}^{2}\right)$ are far below the commonly reported range for these species. Indeed one of the most puzzling aspects of algal distribution in the Great Lakes is occurrence of species whose usual range is marine, such as the red algae Bangia atropurpurea (Roth) Agardh (Kishler \& Taft, 1970; Lin \& Blum, 1977), or estuarine such as Terpsinoe musica Ehrenb. (Wujek \& Welling, 1981). The most probable explanation appears to be that there are many sites within Great Lakes where concentrated brines are discharged. Sonzogni et al. (1983) estimate that direct point source chloride loadings to the Great Lakes were on the order of $5.5 \times 10^{8} \mathrm{~kg}$ $\mathrm{yr} \quad{ }^{1}$ during the 1970 s. Salinity tolerant forms may become established in these local regions and, in some instances, become adapted to lake conditions and become widely disseminated in the system. Because of this, sediment assemblages may contain both extreme halophobous and some $\alpha$-mesohalobous species. While the presence of the latter populations is indicative of local salinization problems, any attempt to reconstruct average system salinity through a ratio or index is liable to yield nonsensical results.

There are some signals in the Great Lakes sediment record that are difficult to interpret because there are no apparent within system, or even general, analogues. Perhaps the most striking of these is an isolated pulse of small benthic taxa (particularly Fragilaria sensu lato) in the pre-European history of Lake Michigan and Green Bay. Bradbury (1988) has noted similar occurrence in Elk Lakc, Minnesota and J. Wolin (pers. commun.) noted a similar signal in the sediments of Lower Herring Lake, a small lake marginal to Lake Michigan. All of these occurrences fall, within probable error in extrapolating ${ }^{210} \mathrm{~Pb}$ dates, at about the time of the 'Little Ice Age'. Particularly because high relative abundances of 'small Fragilaria' are commonly found in diatom assemblages deposited in immediate post glacial and periglacial (e.g., Haworth, 1976; Rawlence, 1988) and in lakes currently under Arctic conditions (Smol, 1983; Wolfe, 1991), it is tempting to speculate that these atypical assemblages represent a strong climatic signal. Unfortunately, the cores we have examined from the other Great Lakes are either too short, or were sampled at inappropriate intervals, to detect this signal. Further research on this particular phenomenon seems warranted, since it could produce a reliable marker of abrupt climate change and an independent date horizon.

The most difficult changes to interpret in the entire Great Lakes sedimentary diatom record are those which have occurred most recently, particularly in least anthropogenically perturbed parts of the system. In Lake Superior (Stoermer et al., $1985 \mathrm{c}$, in press), recently deposited assemblages are substantially different from any which have occurred in the previous record sampled. The same situation is true, to a lesser degree, in the lower lakes, although the situation is more complicated in these parts of the Great Lakes system due to management interventions designed to limit nutrient inputs. In the Lake Superior case, the most striking change is an overall increase in diatom concentration in the sediments and a gross increase in absolute and relative abundance of certain Cyclotella species, most notably the $C$. comensis complex. Similar changes have apparently also occurred in inland lakes in northern Michigan (Fritz et al, in press; Wolin, 1992). In these cases, relative abundance data, whether used in the traditional indicator species concept or with more objective statistical calibrations, yields incongruous result. A more oligotrophic state is forecast by either approach despite increasing diatom abundance. It may be that this is a size-related artifact, in that the main species to increase are small, but I doubt this explanation, based on the limited size differences of species involved and the fact that biogenic silica concentrations show the same trends as diatom abundance data. In any case, it is clear that some factor or factors are driving Great Lakes diatom assemblages to a new state. Two possible factors suggest themselves. The first is a modification of 
nutrient ratios, probably through atmospheric loading. Data from Lake Huron (Stoermer \& Kreis, 1980) suggest that $C$. comensis is particularly favored by high nitrate levels, and it is well established that nitrate concentrations in the Great Lakes have substantially increased in recent years (Weiler, 1978; Stevens \& Neilson, 1987; Rockwell et al., 1989). The other is that current conditions particularly favor diatom populations which occupy the subthermocline niche during summer stratification. This could result from increased solar flux, increased water transparency, or from more prolonged stratification. Unfortunately, evidence to evaluate these possibilities is not presently at hand, but understanding them may be important, because large scale departures in regional climate are implicated.

\section{Conclusion}

Paleolimnologic studies of the Great Lakes have provided a valuable context within which to evaluate historic system changes and perhaps flag the beginnings of important future trends. In nearly all cases, interpretation depended upon extensive previous knowledge of physical constraints on diatom production in these large, complex systems. Without this knowledge, interpretations would clearly have been, at best, ambiguous, and at worst, clearly incorrect. This experience should be cautionary, particularly to investigators working on large systems and, one must suspect, to investigators working on classes of small lake systems that have not been adequately studied.

\section{Acknowledgements}

A large number of past and present colleagues, students and employees have contributed analytical skills and ideas to the work I have attempted to briefly encapsulate here. Although they should be held blameless for my conclusions, I would be remiss if I did not particularly thank; J. J. Yang for help in developing the taxonomic data base which supported later analyses, T. B. and
B. G. Ladewski for help in developing and implementing analytical approaches, R. J. Stevenson and J.C. Kingston for their work on benthic communities, M. L. Tuchman for work on salinity effects, E. C. Theriot for insights on ecological control of morphology, R. G. Kreis, Jr. for work on mapping modern assemblages, M. B. Bowman and L. C. Frey for analyses of modern populations, J. A. Wolin, G. Fimmert, and M. B. Edlund for analyses of sedimentary assemblages, D. J. Conley for chemical analyses, and J. P. Kociolek, who claims to have developed a permanent aversion to centric diatoms from enumerating Great Lakes sedimentary assemblages. J. A. Robbins has been most gracious in providing samples and his expertise in radiometric dating. Most of the work discussed was carried out in collaboration with C.L. Schelske and was supported by Grants from NSF and EPA. EPA Grant R-816467 supported this synthesis, Contribution No. 556 of the Center for Great Lakes, University of Michigan.

\section{References}

Baldwin, N. S. \& R. W. Saalfield, 1962. Commercial fish production in the Great Lakes, 1867-1960. Great Lakes Fisheries Commission Technical Report No. 3, $166 \mathrm{pp}$.

Beeton, A. M., 1966. Indices of Great Lakes eutrophication. In Proceedings of the Ninth Conference on Great Lakes Research, pp. 1-8. Universicy of Michigan, Great Lakes Research Division Publication No. 15.

Beeton, A. M., 1969. Changes in the Environment and Biota of the Great Lakes. In Eutrophication, Causes, Consequences and Correctives, p. 150-187. National Academy of Sciences, Washington, D.C.

Bradbury, J. P., 1988. A climatic-limnologic model of diatom succession for paleolimnological interpretation of varved sediments at Elk Iake, Minnesota. J. Paleolimnol.1: 115130.

Brunel, J., 1956. Addition du Stephanodiscus à la flore diatomique l'Anérique du Nord. Le Naturaliste Canadien 83 : $89-95$.

Engstrom, D. R., E. B. Swain \& J. C. Kingston, 1985. A paleolimnological record of human disturbance from Harvey's Lake, Vermont: geochemistry, pigments and diatoms. Freshwat. Biol. 15: 261-288.

Fahnenstiel, G. L. \& J. M. Glime, 1983. Subsurface chlorophyll maximum and associated Cyciotela pulse in Lake Superior. Int. Revue ges. Hydrobiol. 68: 606-616. 
Frederick, V. R., 1981. Preliminary investigation of the algal flora in the sediments of Lake Erie. J. Great Lakes Res. 7: 404-408.

Fritz, S.C, J.C. Kingston \& D. R. Engstrom, in press. Quantitative trophic reconstruction from sedimentary diatom assemblages: a cautionary talc. Freshwater Biology.

Håkansson, H., 1986. A taxonomic reappraisal of some Stephanodiscus spccies (Bacillariophyta). Br. Phycol. J. 21: $26-37$.

Hăkansson, H. \& E. F. Stoemer, 1984. Observations on the type material of Siephonodiscus hantzschii Grunow in Cleve and Grunow. Nova Hedwigia 39: 477-496.

Harris, G. P. \& R. A. Vollenweider, 1982. Paleolimnological evidence of early cutrophication in Lake Erie. Can. J. Fish. aquat. Sci 39: 618-626.

Haworth, E. Y., 1976. Two late-glacial (late Detensian) diatom assemblage profiles from northern Scotland. New Phytol. 77: 227-276.

Herdendorf, C. E., 1982. Large lakes of the world. J. Great Lakes Res. 8: $379-412$.

Hohı, M. H., 1969. Qualitative and quantitative analysis of plankton diatoms, Bass Island area, Lake Erie. Bull Ohio Biol. Surv., New Series, 3: 1-211.

Holland, R. E. \& L. W. Claflin, 1975. Horizontal distribution of planktonic diatons in Green Bay, Mid-July 1970. Limnol. Oceanogr. 20:366-378.

Huang, J. C. K., 1972. The thermal bar. Geophys. Fluid Dyn, 3: $1-25$.

Hutchinson, G. E., 1967. A Treatise on Limnology. Vol. II. Introduction to Lake Biology and the Limnoplankton. John Wiley \& Sons, New York, NY.

Karrow, P. F, \& P. E. Calkin, 1985. Quaternary Evolution of the Great Lakes. Geological Association of Canada, Special Paper No. 30.

Kingston, J, C., R. L. Lowe, E. F. Stoerner \& T. B. Ladewski, 1983. Spatial and temporal distribution of benthic diatoms in northern Lake Michigan. Fcology 64: 1566-1580.

Kishler, J. \& C. E. Taft, 1970. Bangia arropurpurea (Roth) A. in western Lake Erie. Ohio J. Sci. 70: 56-57.

Lin, K. C. \& J. L. Blum, 1977. Recent invasion of a red alga (Bangia atopurpurea) in Lake Michigan. J. Fish. Res. Bd Can. 34: 2413-2416.

Lorifice, G. J. \& M. Munawar, 1974. The abundance of diatoms in the southwestern nearshore region of Lake Ontario during the thermal bar period. In Proceedings of the Seventeenth Conference on Grcat Lakes Research, Intemat. Assoc. Great Lakes. Res: 619-628.

Mack ay, H. H., 1930. Pollution problems in Ontario. Trans. amer. Fish. Soc. 60: 297-306.

Mills, F. I.., J. H. Leach, J. T. Cariton \& C. L. Secor, 1991. Exalic species in the Great Lakes: $\triangle$ history of biotic crises and anthropogenic introductions. Great Lakes Fishery Commission, Ann Arbor, MI $117 \mathrm{p}$.

Moll, R. A. \& E. F. Sioermer, 1982. A hypothesis relating trophic status and subsurface chlorophyll maxima of lakes. Arch. Hydrobiol. 94: 426-440.
Parker, J. I. \& D. N. Edgington, 1976. Concentration of diatom frustules in Lake Michigan sediment cores. Limnol. Oceanogr, 21: 887-893.

Parsons, J. W., 1973. History of Salmon in the Great Lakes, 1850-1970. U.S. Bureau of Sport Fisheries and Wildlife Technical Paper No. 68.

Peterson, R. R., 1975, A paleolimnological study of the eutrophication of Lake Erie. Verh. int Ver. Limnol. 19. 2274-2283.

Quinn, F. H., 1992. Hydraulic residence limes for the Great Lakes. J. Great Lakes Res. 18: 22-28.

Rawlence, D. P., 1988. The post-glacial diatom history of Splan Lake, New Brunswick. J. Palcolimnol. 1: 61-60.

Rockwell, D. C., D. K. Salisbury \& B. M. Lesht, 1989. Water qualicy in the middle Great I akes: Results of the 1986 U.S. EPA Survey of Lakes Frie, Huron and Michigan. U.S. Environmental Protection Agency F.PA-906,6/89-001. U.S. Environmental Protection Agency, Great Lakes National Program Office, Chicago, Illineis.

Schelske, C. L., 1991. Historical nutrient enrichment of Lake Ontario: paleolimnological evidence Can. J. Fish. aquat. Sci. 48: 1529-1538.

Schelske, C. L. \& E. F. Stoermer, 1971. Eutrophication, sil ica depletion and predicted changes in algal quality in Lake Michigan. Science 173: 423-424.

Schelske, C. L. \& E. F. Stoermer, 1972. Phosphorus, silica and eutrophication of Lake Michigan. In G. E. Likens (ed.), Nutrients and Eutrophication. Amer. Soc. Limnol. Oceanogr., Spec. Symp., Vol. I, p. 157-17I.

Schelske, C. L. \& E. F. Stoermer, 1984. Limnological characteristics of northern Lake Michigan, 1976. Part 2: Phytoplankton population studies. Univ. Michigan, Great Lakes Res. Diw. Spec. Rep. No. 96.245 p.

Schelske, C. L., E. F. Stoermer, D. J. Conley, J. A. Robbins \& R. M. Glover, 1983. Early eutrophication of the lower Great Lakes: New evidence from biogenic silica in the sediments. Science 222: 320-322.

Schelske, C. L., E. F. Stoermer, G. L. Fahnenstiel \& M. Haibach, 1986. Phosphorus enrichment, silica utilization and silica depletion in the Great Lakes. Can. J. Fish. aquat. Sci. 43: $407-416$.

Schelske, C. L., J. A. Robbins, W. D. Gardner, D. J. Conley \& R. A. Bourboniere, 1988. Sediment record of biogeochemical responses to anthropogenic perturbations of nutrient cycles in lake Ontario. Can. J. Fish. aquat. Sci. 45: 1291-1303

Schindler, D. W., 1985. The Coupline of Elemental Cycles by Organisms: Evidence from Wholc-Lake Chemical Perturbations. In W. Stumm (ed.), Chemical Processes in Lakes, p. 225-250. John Wiley \& Sons, New York, NY.

Sell, D. W., H. J. Carney \& G. L. Fahnenstiel, 1984. Inferring compelition between natural phytoplankton populations: the Lake Michigan example reexamined. Ecology 65: 325328.

Sicko-Goad, L. \& E. F. Stoermer, 1988. Effects of toxicants on phytoplankton with special reference to the Laurentian 
Great Lakes. Chapter 1, p. 1-19. In: Toxic Contamination and Ecosystem Health - A Great Lakes Focus (M. S. Evans, ed.). Advances in Environmental Science and Technology Vol. 21. John Wiley and Son, New York.

Sicko-Groad, L., E. F. Stoermer \& J. P. Kociolek, 1989. Diatom resting cell rejuvenation and formation: Time course, species records and distribution. J. Plankton Res. 11: 375389.

Smith, S. H., 1972. Destruction of the ecosystem in the Great Lakes and possibilities for its reconstruction. University of Washington Publications in Fisheries, New Series 5: 4146.

Smol, J. P., 1983. Palecphyeology of a high arctic lake near Cape Herschel, Ellesmere Island. Can. J. Bot. 61: 21962204.

Sonzogni, W. C., W. C. Richardson, P. Rogers \& T. J. Monteith, 1983. Chloride pollution of the Great Lakes. J. Wat. Pollut. Cont. Fed. 55: 513-521.

Stevens, R. J. J \& M. A. Neilson, 1987. Response of Lake Ontario to reductions in phosphorus load, 1967-82. Can J. Fish. aquat. Sci. 44: 2059-2068.

Stoermer, E. F., 1968. Nearshore phytoplankton populations in the Grand Haven, Michigan, vicinity during thermal bar conditions. Proc. 11 th Conf. on Great Lakes Res., p. 137150. Internat. Assoc. Great Lakes Res.

Stoermer, E. F., M. M. Bowman, J. C. Kingston \& A. L. Schdedel, 1974. Phytoplankton composition and abundance in Lake Ontario during IFYGL. Univ. Michigan, Great Lakes Res. Div. Spec. Rep. No. 53.373 p.

Stoermer, E. F. \& T. B. Ladewski, 1976. Apparent optimal temperatures for the occurrence of some common phytoplankton species in southern Lake Michigan. Univ. Michigan, Great Lakes Res. Div. Publ. No. 18. 49 p.

Stoermer, E. F. \& T. B. Ladewski, 1978. Phytoplankton associations in Lake Ontario during IFYGI. Univ. Michigan, Great Lakes Res. Div. Spec. Rep. No. 62.106 p.

Stocrmer, E. F., J. C. Kingston \& L. Sicko-Groad, 1979. The morphology and taxonomic relationships of Stephanodiscus binderams var. oestrupi (A. Cl.) A. Cl. Nova Hedwigia, Beih. 64: 66-78.

Stoermer, E. F. \& R. G. Kreis, Jr., 1980. Phytoplankton composition and abundance in southern Lake Huron. U.S. Enviromnental Protection Agency, Research Reporting Series EPA-600/3-80-061, Environmental Research Laboratory, Duluth, MN. $382 \mathrm{p}$.

Stoermer, E. F. \& R. J. Stevenson, 1980. Green Bay phytoplankton composition, abundance and distribution. U.S. Environmental Protection Agency, Great Lakes National Program Office, Chicago, IL. 103 p.

Stuermer, E. F. \& H. Håkanssun, 1984. Stephanodiscus parvus: Validation of an enigmatic and widcly misconstrucd taxon. Nova Hedwigia 39: 497-511.

Stoermer, E. F., J. A. Wolin, C. L. Schelske \& D. J. Conley, 1985a. An assessment of ecological changes during the recent history of Lake Ontario based on siliceous microfossils preserved in the sediments. J. Phycol. 21: 257-276.
Stoermer, E. F., J. A. Wolin, C. L. Schelske \& D. J. Conley, 1985b. Post settlement diatom suecession in the Bay of Quinte, Lake Ontario. Can. J. Fish. aqual. Sci. 42: 754767.

Stoermer, E. F., J. P. Kociolek, C. L. Schelske \& D. J. Conley, 1985c. Siliceous microfossil succession in the recent history of Lake Superior. Proc. Acad. Nat. Sci., Philadelphin 137: 106-118.

Stoermer, E. F., J. A. Wolin, C. L. Schelske \& D. J. Conley, 1985 d. Variations in Melosira islandica valve morphology in Lake Ontario sediments related to eutrophication and silica depletion. Limnol. Oceanogr. 30: 414-418.

Stoermer, E. F., J. P. Kociolek, C. L. Schelske \& D. J. Conley, 1987. Quantitative analysis of siliceous microfossils in the sediments of Lake Erie's central basin. Diatom Research 2: 113-134.

Stoermer, E. F., G. Emmert \& C. L. Schelske, 1989. Morphological variation of Stephanodiscus niagarae (Bacillariophyta) in a Lake Ontario sediment core. J. Paleolimnol. 2: 227-236.

Stoermer, E. F., J. A. Wolin, C. L. Schelske \& D. J. Conley, 1990a. Siliceous microfossil succession in Lake Michigan. Limnol. Oceanogr. 35: 959-967.

Stoermer, E. F., C. L. Schelske \& J. A. Wolin, 1990b. Siliceous microfossil succession in the sediments of McLeod Bay, Great Slave Lake, Northwest Territories. Can. J. Fish aquat. Sci. 47: 1865-1874.

Stoermer, E. F., J. P. Kociolek, C. L. Schelske \& N. A. Andresen, 1991. Siliceous microfossil succession in the recent history of Green Bay, Iake Michigan. J. Paleolimnol. 6: $123-140$.

Stoermer, E. F., J. A. Wolin \& C. L. Schelske, In press. Paleolimnological comparison of the Laurentian Great. Lakes based on diatoms. Limnol. Oceanogr

Thayer, V. I.., T. C. Johnson \& H. J. Schrader, 1983. Distribution of diatoms in Lake Superior sediments. J. Great Lakes Res. 9: 497-507.

Theriot, E. C., 1987. Principal component analysis and taxonomic interpretation of environmentally related variation in silicification in Stephanodiscus (Bacillariophyceae). Br. Phycol. J, 22: 64-72.

Theriot, E. C. \& E. F. Stoermer, 1984. Principal components analysis of character variation in Stephanodixcus niagarae Ehrenb.: Morphological variation related to lake trophic status. p. 97-111. Proceedings of the VII ${ }^{\text {th }}$ International Diatom Symposium, Philadelphia. Otto Koeltz, Koenigstein.

Theriot, E. C. H. Hakansson \& E. F. Stoermer, 1988. Morphometric analysis of Stephanodiscus alpinus (Bacillariophyceae) and its morphology as an indicator of lake trophic status. Phycologia 27: 485-493.

Tilman, D., 1977. Resource competition between planktonic algae: an experimental and theoretical approach. Ecology 58: $338-348$.

Vollenweider, R. A., M. Munawar \& P. Stadelmann, 1974. A comparative review of phytoplankton and primary produc- 
Lion in the Laurentian Great Lakes. J. Fish. Res. Bd. Can. 31: 739-762.

Weiler, R, R, 1978. Chemistry of Lake Superior. J. Great Lakes Re3, 4: 370-385.

Wolfe, A. P., 1991. Mid and late Holocene diatoms from 'Water Supply Lake', Baffin Island, N. W. T., Canada. J. Paloolimnol. 6: 199-204.

Wolin, I. A., 1992. Paleoclimatic implications of late Holocene lake-level fluctuations in Lower Herring Lake, Michigan. Unpublished doctoral dissertation, School of Natural Re- sources and Environment, University of Michigan, $155 \mathrm{p}$. Wolin, J. A., E. F. Stoermer, C. L. Schelske \& D. J. Conley, 1988. Siliceous microfossil succession in recent Lake Huron sediments. Archiv. Hydrobial, 114: 175-198.

Wolin, J. A., E. F. Stoermer \& C. L. Schelske, 1991. Recent changes in Lake Ontario 1981-1987: Microfossil evidence of phosphorus reduction. J. Great Lakes Res. 17: 229-240.

Wujek, D. E. \& M. L. Welling, 1981. The occurrence of two centric diatoms new to the Great Lakes. J. Great Lakes Res. 7: 55-56. 